\title{
Toward Identification of the Priority Lines of Research in Nanotechnology on the Basis of the Technology Foresight NT for Podlaskie 2020
}

\author{
J. Ejdys and E. Glinska
}

\begin{abstract}
Foresight projects have been used across the world in the process of anticipating the future by governments, regional authorities, companies and S\&R institutes. Foresight, together with its specific research tools and terminology, is becoming increasingly important also in Poland. From nearly 50 foresight projects implemented in Poland most of them is related with the technology and research development. The key issue of foresight methodology is to identify the key technologies/priority line of research. The paper presents a methodology of selection of priority lines of research in nanotechnology at regional scale.
\end{abstract}

Index Terms-Nanotechnology, priority line of research, technology foresight.

\section{INTRODUCTION AND TECHNOLOGY FORESIGHT}

The most often quoted definition of foresight is that from B. Martin who describes research foresight as "the process involved in systematically attempting to look into the longer-term future of science, technology, the economy and society with the aim of identifying the areas of strategic research and the emerging generic technologies likely to yield the greatest economic and social benefits" [1]. The development of foresight has occurred as a response to changes that have taken place in the world economy. Some of the main drivers of change in the global economy over coming decades - according to B. Martin [2] - are: increasing competition, increasing constraints on public expenditure, increasing complexity and increasing importance of scientific and technological competencies. These factors also underlie the upsurge of interest in foresight, giving rise to its emergence as a global concept and policy tool.

For several decades, foresight projects have been used across the world in the process of anticipating the future. International organisations, governments, regional authorities, companies and science and research institutes use foresight to build visions of the future of countries, regions, economic sectors and technologies. Foresight, together with its specific research tools and terminology, is becoming

Manuscript received January 15, 2013; revised March 29, 2013. This work is result of the research project Technology Foresight $<$ NT for Podlaskie 2020>> Regional Strategy of Nanotechnology Development, financed by the EU under the Operational Programme Innovative Economy. The project's beneficiary is Bialystok University of Technology. The project is implemented in the period 2009-2013 and its time perspective extends up to 2020 .

J. Ejdys and E. Glinska are with the Faculty of Management, Bialystok University of Technology, Wiejska Street 45 A, 15-351 Bialystok, Poland (e-mail: j.ejdys@pb.edu.pl, e.glinska@pb.edu.pl). increasingly important also in Poland. This is confirmed by the continuously extending catalogue of Polish foresight initiatives (both completed and ongoing), which, as for 2012, included more than 40 items [3].

A central subcategory of futures research is technology foresight [4]. L. Georghiou describes technology foresight as "a systematic means of assessing those scientific and technological developments which could have a strong impact on industrial competitiveness, wealth creation and quality of life" [1]. Technology foresight is both the process and the tool, with the help of which the consensus of scholars, engineers, representatives of industry, workers of public administration as well as wide society is obtained [5]. Technology foresight has a variety form in terms of their sponsorship, focus, methods, target users, time horizon, geographical scope, etc., but is frequently utilised to identify future emerging technologies and the future scenario for prioritisation of $R \& D$ investment. Recent booming is not just a phase; but rather the result of strong strategic intention. Technology foresight can make a unique strategic contribution to the policy maker as well as to social stakeholders, especially in the S\&T related area. It is about promoting the national (or regional) competitiveness through thinking, debating, and shaping the future [6].

\section{Prioritization of Research Directions AND KeY TECHNOLOGIES AS ONE OF MAIN OBJECTIVES OF FORESIGHT PROJECTS}

Objectives of foresight projects are varied. However, in the literature on the subject, attempts of their classification can be found. L. Georghiou and J. C. Harper [7] have analysed 50 foresight initiatives described in the European Foresight Monitoring Network (EFMN) database. The analysis of the initiatives has led to identifying 199 various objectives of foresight projects. Subsequently, a classification of the objectives was developed. The largest group within the classification includes those objectives which the authors classified into the category "analysis of future potential of technology" "(in total, $22 \%$ of all the objectives were classified into this group). The group includes such objectives of foresight projects which preselect one or more fields of science and technology, and use the foresight approach to assess their potential and to determine measures necessary to support their development. The second largest group of foresight objectives includes those which relate to supporting a particular development direction of a policy or business strategy (the group includes $17 \%$ of all 
the objectives of foresight projects). The third group (comprising about $14 \%$ of the objectives) includes those which relate to promoting the development of cooperation networks between actors in research and innovation. Objectives related to prioritizing science and technology development directions constitute about $11.5 \%$ of all the identified objectives of the analysed foresight initiatives. The authors have also distinguished the following groups of foresight project objectives: methodology and capacity building, and articulating supply and demand (each comprising $9.5 \%$ of all the identified objectives), as well as public engagement (5.5\%) [7].

As regards Polish foresight initiatives, a similar analysis carried out by a team of researchers headed by J. Nazarko indicated that the objectives of the first regional and sectoral foresight projects implemented in Poland included primarily [3]: assessment of the state of technology in a specific sector/industry; identification of solutions with the greatest development potential; assessment of innovation potential of specific technologies; identification of key technologies of strategic importance for the development of the country/ region, or for sustainable development; and determination of priorities in the field of $R \& D$ in the region.

It should be noted that prioritisation of research directions is one of the main objectives of foresight projects pursued both in Poland and in other countries. Moreover, in the practice of foresight studies, it is difficult to separate objectives relating to determination of priority research directions from those relating to identification of key technologies, as in many aspects the two areas are closely related. The criteria of determination of priority research directions, applied in foresight projects, are often the same as the criteria used in identifying key technologies related to the research area covered by a given project.

\section{CRITERIA OF DETERMINATION OF PRIORITY RESEARCH DIRECTIONS IN FORESIGHT PROJECTS}

Determination of key technologies/priority research directions relevant to the objectives of the project is one of the most difficult elements of foresight studies. Based on literature studies and analysis of selected foresight projects implemented in Europe, the criteria used in identifying key technologies/priority research directions have been determined. The results of the study are shown in Table I.

Among the criteria considered in the process of selecting key technologies/ research directions there are criteria which relate to possibilities of implementing and applying the research results, as well as the criteria which determine the research directions' impact onto the surrounding environment. The conducted literature studies have proven that research teams use different criteria in evaluating research directions to identify those of key importance. In the opinion of the authors, the target set of criteria should include three groups: economic criteria, social criteria and environmental (ecological) criteria. This is important in the context of sustainable development. The foresight projects analysed by the authors were characterized by a relatively high degree of differentiation of the criteria used in assessing technology/ research development directions. The conducted literature studies have allowed to identifying good practices in the selection of key technologies/ research directions (Table II).

TABLE I: CRITERIA OF DETERMINATION OF PRIORITY RESEARCH DIRECTIONS

\begin{tabular}{|c|c|}
\hline $\begin{array}{l}\text { Author of } \\
\text { publication }\end{array}$ & $\begin{array}{l}\text { Adopted criteria of determination } \\
\text { of key technologies/ priority } \\
\text { researchdirections }\end{array}$ \\
\hline $\begin{array}{l}\text { Gi, Ho Jeong; } \\
\text { Soung, Hie } \\
\text { Kim (1997) } \\
{[8]}\end{array}$ & $\begin{array}{l}\text { impact of technology / research on the } \\
\text { development of other technologies / research: } \\
\text { time delay }\end{array}$ \\
\hline $\begin{array}{l}\text { A. Rogut } \\
(2011) \\
{[9]}\end{array}$ & $\begin{array}{l}\text { social validity (public health, food quality, } \\
\text { consumer and new consumption patterns, food } \\
\text { safety, proper food manufacture, food chain } \\
\text { management, social responsibility of science, } \\
\text { environmental friendliness) } \\
\text { growth potential (international position, scope } \\
\text { and quality of scientific and technological } \\
\text { competence now and in the future; research and } \\
\text { development infrastructure; organisational } \\
\text { efficiency; financing; importance strategy for } \\
\text { the national food industry; maturity of } \\
\text { technology) }\end{array}$ \\
\hline $\begin{array}{l}\text { A. Rogut, B. } \\
\text { Piasecki } \\
(2011) \\
{[10]}\end{array}$ & $\begin{array}{l}\text { likelihood of breakthrough discoveries, } \\
\text { possibility of conducting interdisciplinary } \\
\text { research, possible synergies with other research } \\
\text { directions, the existing state of knowledge in a } \\
\text { given area, the necessary level of research } \\
\text { infrastructure, the position of science and } \\
\text { technology }\end{array}$ \\
\hline $\begin{array}{l}\text { T. Ahlqvist } \\
(2005) \\
{[11]}\end{array}$ & $\begin{array}{l}\text { likelihood of technology/ research } \\
\text { development, technology emergence time as a } \\
\text { result of development of scientific research, } \\
\text { social impact (important jobs and qualifications } \\
\text { related to technology; the impact of technology } \\
\text { on the development of the education system; } \\
\text { the likelihood of the emergence of new } \\
\text { professions and qualifications, the likelihood of } \\
\text { the new jobs becoming good practices) }\end{array}$ \\
\hline $\begin{array}{l}\text { J.C Mankins } \\
(1998) \\
{[12]}\end{array}$ & $\begin{array}{l}\text { research and development degree of difficulty } \\
\text { (NASA) }\end{array}$ \\
\hline $\begin{array}{l}\text { C. S. Wagner, } \\
\text { S. W. Popper } \\
(2003)[13]\end{array}$ & $\begin{array}{l}\text { importance of technology/ research for } \\
\text { long-term national security and economic } \\
\text { development }\end{array}$ \\
\hline $\begin{array}{l}\text { T. Durand } \\
(2003) \\
{[14]}\end{array}$ & $\begin{array}{l}\text { industrial and economic support for } \\
\text { technology/ research (current and future size of } \\
\text { the market, the ability to improve the } \\
\text { competitive position, the development } \\
\text { possibilities for companies, the possibility of } \\
\text { mass production and cost reduction), protection } \\
\text { of the environment (sustainable development, } \\
\text { conservation of energy and natural resources, } \\
\text { emissions control and waste management, } \\
\text { possible negative impact of technology on the } \\
\text { environment), social needs (health and hygiene, } \\
\text { food safety, aging, culture, education and } \\
\text { training, possibility of negative impacts), } \\
\text { national and European security (security and } \\
\text { defence, independence of industry). }\end{array}$ \\
\hline
\end{tabular}

One of the good practices is the application of different criteria depending on the stage of the process of selecting key technologies/ research directions. As an example, a French project may be mentioned where in the first stage of selecting candidate technologies, a broad spectrum of different criteria 
was used, which was subsequently altered and narrowed at the stage of selecting key technologies.

TABLE II: GOOD PRACTICES IN SELECTING KEY TECHNOLOGIES/ PRIORITY RESEARCH DIRECTIONS IN FORESIGHT PROJECTS

\begin{tabular}{|c|c|}
\hline Country & Good practices \\
\hline $\begin{array}{l}\text { France, } \\
\text { Japan }\end{array}$ & $\begin{array}{l}\text { Periodic implementation (e.g. every } 5 \text { years) of foresight } \\
\text { projects/ programmes, which enables continuous } \\
\text { improvement of previously achieved results and adopted } \\
\text { project methodologies, and to verify technology/ } \\
\text { research directions' evaluation criteria. }\end{array}$ \\
\hline France & $\begin{array}{l}\text { Perception of technology foresight studies from a } \\
\text { perspective broader than the perspective of the country. It } \\
\text { is necessary to take into account the European and global } \\
\text { perspectives, which allows to assess the impact of } \\
\text { technology research e.g. on the country's competitiveness } \\
\text { across Europe and the world. }\end{array}$ \\
\hline France & $\begin{array}{l}\text { Identification of key technologies/ research should take } \\
\text { into account not only the supply side, but also the demand } \\
\text { side in terms of what needs are going to be met as a result } \\
\text { of implementation of a given technology. }\end{array}$ \\
\hline $\begin{array}{l}\text { France, } \\
\text { Poland }\end{array}$ & $\begin{array}{l}\text { Identification of key technologies/ research should take } \\
\text { into account the relationship between the technologies } \\
\text { and research directions which over time become more } \\
\text { recognisable. In the context of determining technologies/ } \\
\text { research directions, it is important to determine the causal } \\
\text { relationships between the technologies and the effects of } \\
\text { their implementation. In creating technology roadmaps, it } \\
\text { is useful to relate the characteristics of research directions } \\
\text { to previously identified key technologies }\end{array}$ \\
\hline Brazil & $\begin{array}{l}\text { The variety of evaluation criteria in more narrow fields } \\
\text { (sectors) makes it possible to better capture the } \\
\text { specificity of the given sector. }\end{array}$ \\
\hline $\begin{array}{l}\text { The } \\
\text { Netherla } \\
\text { nds }\end{array}$ & $\begin{array}{l}\text { Acknowledging that foresight projects play a significant } \\
\text { role in technology implementation and transfer } \\
\text { brokerage. }\end{array}$ \\
\hline Finland & $\begin{array}{l}\text { Foresight projects should present a holistic approach, } \\
\text { consisting in proposing where exactly the solutions } \\
\text { developed within specific research areas can be used, and } \\
\text { what governmental policy tools can strengthen the } \\
\text { development of a given research area. }\end{array}$ \\
\hline Japan & $\begin{array}{l}\text { The involvement of decision-makers from ministries } \\
\text { allows better incorporation of report results into the } \\
\text { content of developed strategic documents of the country. } \\
\text { Within the project, research directions and technologies } \\
\text { for industry were recommended for financing from } \\
\text { private funds, in addition to public funding. }\end{array}$ \\
\hline $\begin{array}{l}\text { Austria, } \\
\text { Poland, } \\
\text { Sweden }\end{array}$ & $\begin{array}{l}\text { Acknowledging the role of social consultations in the } \\
\text { implementation of foresight projects }\end{array}$ \\
\hline
\end{tabular}

Source: J. Nazarko, J. Ejdys, K. Halicka, E. Glińska, A. Pawluczuk, and A Gudanowska, Identyfikacja dobrych praktyk eksploracji kierunków rozwoju badań naukowych oraz technologii w badaniach foresightowych; Narodowy Program Foresight - Wdrożenie Wyników, Bialystok 2012 (photocopied material) [15].

The analysis of results of Polish and foreign foresight projects has allowed to indicate those elements and features of the process of identifying key technologies/ research directions which are decisive for their future practical relevance. These include [15]:

1) A clear, transparent and systematised evaluation system that facilitates the adaptation of the procedure in other foresight initiatives.

2) Research narrowed to and focused on specific thematic groups or technology/research groups.

3) Smaller number of determined research directions/technologies ensures a higher level of specialisation and concentration of human and financial resources;

Application of a relatively broad set of criteria in evaluating technologies/research directions.

1) The use of graphic tools in the presentation of results.

2) The use of IT tools in the course of research.

3) Data collection in constantly updated databases.

4) Linking foresight project results to strategic development programmes of a unit/region/country in the field of innovation.

5) Integration of scientific approach and business (industrial) technology commercialization of research results.

The good practices determined in the paper and relating to identification and evaluation of technologies and research directions should be the starting point in formulating the assumptions of the key technology selection methodology. The experience of other countries in this field, evaluated as highly useful, may serve as a model for those implementing future projects aimed at foreseeing the state of science and technology.

\section{BRIEF CHARACTERISTICS OF THE PROJECT TECHNOLOGY FORESIGHT NT FOR PODLASKIE 2020}

The research project Technology Foresight NT for Podlaskie 2020. Regional Strategy of Nanotechnology Development is financed by the EU. It is implemented in the period 2009-2013 and its time perspective extends up to 2020. The project is focused on determining strategic development directions for the Podlaskie region, based on the assumption of rapid growth in productivity due to control and implementation of innovative production and processing processes which employ achievements in nanotechnology. The main research methodology consists in foresight studies [16].

The Podlaskie region is one of the less economically developed regions of Poland, characterised by lower standards of living. Low competitiveness of the region's location and low level of innovation in technologies, processes and products translates into low interest in investing in the region, observed on the side of both national and international capital [16]. Therefore, according to the project authors, the Podlaskie region's development opportunities should be sought in two areas of activity, contradictory to the earlier approach to socio-economic development policy [17]: a) application of modern tools in determining the future state of reality, b) research on cutting-edge technologies on which the region's future development could be based.

The presented project, therefore, according to the intention of the authors, aims to present the possibility of a breakthrough in the future development of the Podlaskie region by turning away from the traditional industries and moving towards nanotechnology-based production.

The main objective of this technology foresight project is the projection of the Podlaskie region's nanotechnology development strategy until 2020, which means determination of the Podlaskie region's priority directions focused on the use of nanotechnology and identification of the region's key scientific research and technological trajectories in the field of nanotechnology [17]. The project distinguishes three main 
research areas [17]: first: "Nanotechnology in the Podlaskie region's economy", second: "Scientific research in nanotechnology, aimed at the development of the Podlaskie region" and third: "Key factors in nanotechnology development in the Podlaskie region".

The subject of studies within the second research area is the analysis and identification of future research directions which should be adopted by the Podlaskie region's research centres in order to support the development of nanotechnology.

\section{SElEction of Priority Directions of RESEARCH IN THE FIELD OF NANOTECHNOLOGY WITHIN THE PROJECT "NT FOR PODLASKIE 2020"}

The main research method used to identify, in the first place, research directions of key importance for the development of the Podlaskie region and its competitiveness was a method based on evaluating the candidate research directions against two criteria: attractiveness and feasibility [18], [19]. This approach was developed by prioritisation of key research directions. The criterion of the prioritisation was the evaluation of degrees of research difficulty, to which specific probabilities of success in achieving the assumed research objectives were assigned.

In line with the general research methodology adopted for the project, the main research works were implemented by panels of experts whose tasks included development, analysis and synthesis of knowledge relevant to the individual subjects. Research works carried out within one of the panels, the so-called (POB2) Panel relating to the research area "Scientific research in nanotechnology for the development of Podlaskie", aimed to identify such trajectories of scientific research in nanotechnology, which are of key significance for the development of the region. In the work of the panel, 27 experts from across Poland, representing the fields of science, business and administration, were involved.

The panel's works on compiling the list of priority research directions consisted of the following six research tasks [20]: development of a preliminary catalogue of research directions, determination of research directions' evaluation criteria, determination of key research directions, development of guidelines for prioritising the research directions, prioritising the research directions and development of a catalogue of priority research directions.

The individual research tasks were performed in a sequence. The results of completed tasks constituted input information for the research tasks to follow. The end result is the development of a list of key areas of research in the field of basic and applied sciences, as well as their prioritisation. The methods used in the work of the panel included: expert panel and workshops; literature survey and bibliometric analysis; traditional-form brainstorming and brainnetting, and questionnaire surveys. The set of applied research methods can be mapped into the four dimensions of the Foresight Diamond methodology [21], i.e. 1) creativity (brainstorming, brainnetting), 2) facts (literature survey, bibliometric analysis), 3) expertise (expert panels, questionnaire surveys), 4) interaction (workshops).

The preliminary catalogue of research directions was created as a result of indication, by the experts, of the directions of research in nanotechnology. Ultimately, the list of candidate directions of research in the field of basic sciences included 90 research directions and in the field of applied sciences, the list included 93 research directions; the directions covered the following areas: a) basic sciences: nanomaterials; biotechnology; nanomedicine; mechanical engineering; wood industry; social sciences; b) applied sciences: wood industry; building and road construction; textile industry; nanomedicine; bionanotechnology; agriculture and food industry; information technologies; ICT; energy.

To reduce the number of the determined research directions, an analysis was carried out of the criteria that would enable the process. The conducted literature surveys indicated two groups of criteria used in assessing directions of foresight studies: a) feasibility-related criteria and b) attractiveness-related criteria.

The attractiveness criteria relate to the results of conducted research (impact on socio-economic development or on competitiveness increase). The feasibility criteria relate to the evaluation of existing conditions for scientific research and to its feasibility (staff, infrastructure, potential, sectors).

Finally, a list of 29 feasibility-related criteria and a list of 29 attractiveness-related criteria were obtained. The next stage was to reduce the number of the criteria used for evaluating the candidate research directions to achieve those criteria which are the most useful.

Experts from POB2 Panel were asked to assess the usefulness of the individual criteria, using a 3-point rating scale where 1 meant the criterion's low usefulness in evaluating research directions, 2 meant moderate usefulness and 3 meant high usefulness in evaluating research directions.

The goal was to select the criteria most useful for evaluating the candidate research directions, taking into account the context of regional development of nanotechnology. Finally, for evaluating the research directions, in the group of criteria relating to attractiveness the following criteria were adopted:

1) Innovativeness of the directions of implemented research that is lacking or insufficiently developed in Poland but is needed in own or neighbouring markets.

2) Probability of the development of international scientific cooperation (broadening of international cooperation, including exchange of scientists, students and managers in areas of key importance for development in the region).

3) Possibility of commercialisation of research results.

4) Research directions' impact on further development of $\mathrm{R} \& \mathrm{D}$ infrastructure in the region.

5) Potential impact of conducted research on the development of new industries in the region.

6) Potential impact of conducted research on the development of existing industries in the region.

In the group of criteria relating to feasibility, the following criteria were adopted:

7) Possibilities of research directions' financing by internal and external sources.

8) Ambitious character and uniqueness of research 
direction on the Polish scale, allowing to obtain sufficiently large amounts of money for the development of the region.

9) Existing human resources necessary to conduct research in the region.

10) Existing and expected development of research infrastructure (including Bialystok Science and Technology Park and the University) for the development of future research.

11) Existing advancement of conducted scientific research.

12) The next stage of the study was the evaluation of research directions against the criteria from the two groups: the attractiveness criteria and the feasibility criteria. Experts evaluated the individual research directions on a scale from 1 to 5 , where 1 indicated the lowest degree of attractiveness/feasibility, and 5 indicated their highest degree. Moreover, during the evaluation the experts declared their individual level of knowledge in the field of application of specific research directions. The final evaluation of a given direction was equal to the average of the ratings by individual experts, weighted against the declared level of knowledge.

Based on the information relating to feasibility and attractiveness, a graph was drawn up which presents the individual directions' positions in terms of ratings in both criteria (Fig. 1). The graph shows that there is a clear interdependence of the average ratings against the two groups of criteria (correlation coefficient $r=0.72$ ). This means that if a given research direction was highly evaluated by experts in terms of its attractiveness; it was also highly evaluated in terms of its feasibility.

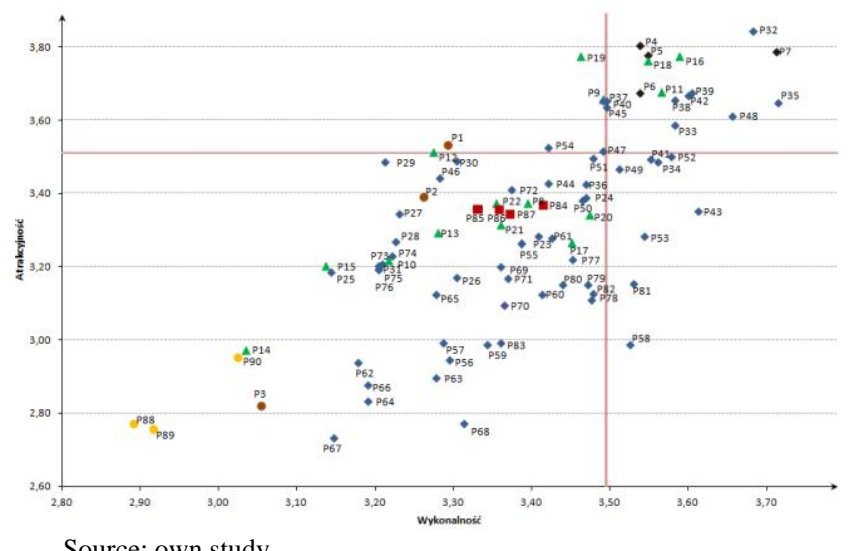

rce: own study

Fig. 1. Basic research directions as evaluated for their attractiveness and feasibility.

The Fig. 1 also includes two lines showing the third quartile level of expert ratings for attractiveness (3.51) and for feasibility (3.50). In this way, the plane was divided into four sections thanks to which out of a large number of basic research directions, those ranked most highly for both attractiveness and feasibility could be selected. A similar graphic interpretation was drawn up for applied research directions.

The results of the evaluation of the candidate research directions against the sets of criteria relating to attractiveness and feasibility, made it possible to reduce the number of criteria to 16 in the group of basic sciences and 16 in the group of applied sciences.

The objective of prioritising the research directions was to compile a list of key research directions, taking into account the factors impacting their development, and to indicate those research directions that are likely to develop most strongly in the Podlaskie region. The prioritising process was carried out using the Research and Development Degree of Difficulty method. The method, developed in 1998 by J. C. Mankins of NASA Office of Space Flight, identifies five degrees of difficulty of research [22]: very low (1), moderate (3), high (3), very high (4) and extremely high (5).

Following a thorough analysis by the Key Team of the project, it was agreed that out of the key research areas, priority should be given to those in which the evaluated degree of difficulty of research guarantees a relatively high probability of success in achieving the research objectives. Ultimately, such features are found on level 3 where the degree of difficulty of research is evaluated as high but is accompanied by the success probability on the level of $80 \%$.

As a result of the conducted expert evaluation, seven priority directions of basic research and five priority directions of applied research have been determined:

1) Basic research: the use of magnetic nanoparticles in the separation of macromolecules and microbes; development of methods for the production of nanostructured materials for regenerative medicine; research on the development of effective micro-biocides and fungicides that do not adversely affect the environment; development of methods for constructing nanoparticles with desired functional properties for biomedical applications; antibacterial nanotechnology; antiseptic materials; implants based on smart materials.

2) Applied research: implant nanomodification, resorbable implants, nanomaterials and nanotechnology for tissue and bone regeneration; biomaterials for tissue engineering (scaffolds), permanent implants.

The results of work of POB2 Panel: Scientific research in nanotechnology for the development of Podlasie will be used in further works within the project Technology Foresight $<<$ NT for Podlaskie 2020 $>>$ Regional Strategy of Nanotechnology Development, in particular in building the strategy o nanotechnology development in the Podlaskie region.

\section{CONCLUSION}

Foresight can be regarded as one of a number of policy tools for engineering major changes required in EU research and innovation policy in the coming years. According to L. Georghiou and J. C. Harper foresight is instrumental in informing the design and implementation of research and innovation policy with three distinctive roles [7]:

1) Corrective role - addressing deficiencies and systemic failures and policy lock-ins.

2) Disruptive role - encouraging an emphasis on crisis or breakthrough events which can completely change the current status quo.

3) Creative role - stimulating the conditions whereby new 
networks and structures can evolve and grow.

The implementation of the project NT FOR Podlaskie is an example of both the disruptive and the creative role of foresight. According to the opinions of experts in the field of regional development of Poland, one of the factors that could contribute to a breakthrough in the current trajectory of industrial development of the eastern parts of Poland (including the Podlaskie region) could be the emergence of the so-called "windows of locational opportunity" as a result of creating clusters of new technologies and raw material exploitation areas [23]. This development concept has been presented in the project NT FOR Podlaskie. It suggests that actors involved in improving the region's competitiveness should place main emphasis on nanotechnology and therefore on the engagement and allocation of funds to scientific research on nanotechnology use in the leading industries of the Podlaskie region.

\section{REFERENCES}

[1] Unido technology foresight manual organizations and methods. Unido Vienna. (2005). [Online]. 1(8). Available: https://www.unido.org/foresight/registration/dokums_raw/volume1_u nido_tf_manual.pdf.

[2] B. Martin, "Technology Foresight in a Rapidly Globalising Economy," presented at the UNIDO Regional Conference on Technology Foresight for Central and Eastern Europe and the Newly Independent States, Vienna, April 2001

[3] J. Nazarko, "Badania ewaluacyjne projektów foresight realizowanych w Polsce," Ministry of Science and Higher Education, Warsaw, 2012, pp. 7.

[4] T. Uotila and H. Melkas, "Quality of data, information and knowledge in regional foresight processes," Futures, vol. 39, pp. 1117-1130, 2007.

[5] A. Magruk, "Innovative classification of technology foresight methods," Technological and Economic Development of Economy, vol. 17, no. 4, pp. 700-715, 2011.

[6] B. Park and S. Son, "Korean technology foresight for national s\&t planning," Int. J. Foresight and Innovation Policy, vol. 6, no. 1/2/3, pp. $166-181,2010$

[7] L. Georghiou and J. C. Harper, "From priority-setting to articulation of demand: Foresight for research and innovation policy and strategy," Futures, vol. 43, pp. 243-251, 2011

[8] H. J. Gi and H. K. Soung, "Qualitative cross-impact approach to find the key technology," Technological Forecasting and Social Change, vol. 55, no. 3, pp. 203-214, 1997.

[9] A. Rogut, Możliwości Wdrożenia Nowych Technologii W PrzetwÓRstwie Rolno-Spożywczym W Świetle Foresight Żywność I Żywienie WXXI W. - Wizja Rozwoju Polskiego Sektora Spożywczego, SWSPiZ, Lodz, 2011.

[10] A. Rogut and B. Piasecki, Metodyka Foresight W: Metodologia Foresightu Technologicznego W Obszarze ZrÓWnoważonego Rozwoju, Instytut Technologii i Eksploatacji - Państwowy Instytut Badawczy, Radom, 2011, pp. 19-20.

[11] T. Ahlqvist, "From information society to bio-society? On societal waves, developing key technologies, and new professions," Technological Forecasting \& Social Change, vol. 72, no. 5, pp. 501-519, 2005.

[12] J. C. Mankins, Research and Development Degree of Difficulty, A White paper, NASA Office of Space Flight, USA, March 1998.

[13] C. S. Wagner and S. W. Popper, "Identifying critical technologies in the united states: a review of the federal effort," Journal of Forecasting, vol. 22, pp. 113-128, 2003
[14] T. Durand, "Twelve Lessons from 'Key Technologies 2005': the French Technology Foresight Exercise," Journal of Forecasting, vol. 22, pp. 161-177, 2003 .

[15] J. Nazarko, J. Ejdys, K. Halicka, E. Glińska, A. Pawluczuk, and A. Gudanowska, Identyfikacja Dobrych Praktyk Eksploracji KierunkóW Rozwoju BadaŃ Naukowych Oraz Technologii W Badaniach Foresightowych, Narodowy Program Foresight - Wdrożenie Wyników, Bialystok 2012 (photocopied material).

[16] J. Nazarko, "Kształtowanie polityki proinnowacyjnej regionu np. Foresightu RTechnologiznego <<NT for Podlaskie 2020〉>," Optimum Studia Ekonomiczne, vol. 2, no. 50, pp. 234-244, 2011.

[17] Feasibility study of Technology foresight, NT FOR Podlaskie 2020, Regional strategy of nanotechnology development, Bialystok 2008, pp 5-6.

[18] K. Klusacek, "Technology foresight in the czech republic," International Journal of Foresight and Innovation Policy, vol. 2, no. 1, 2004.

[19] T. Okulski, "Metody badań foresightowych na przykładzie projektu foresight w górnictwie i hutnictwie Republiki Południowej Afryki," Gospodarka Surowcami Mineralnymi, vol. 24, no. 3/3, 2008.

[20] Scientific research on nanotechnology for the development of the Podlaskie region, within the project Technology Foresight $<<$ NT FOR Podlaskie 2020 >> Regional strategy of nanotechnology development, Project implementation: interim report, Białystok, 2011.

[21] R. Popper, "Foresight methodology," in The Handbook Of Technology Foresight: Concepts and Practice, L. Georghiou, C. J. Harper, M Keenan, I. Miles, and R. Popper (Ed.), Publisher Edward Elgar, 2008, pp. $44-88$.

[22] J. C. Mankins, "Research and development degree of difficulty," A White paper, NASA Office of Space Flight, USA, March 1998.

[23] B. Domański et al. (2011). Znaczenie Przemysłu Dla Inteligentnego I Trwałego Rozwoju Regionu Polski Wschodniej Oraz Podejmowanych DziałaN Dotyczących Jego Restrukturyzacji I Modernizacji. Exper opinion requested by the Ministry of Regional Development. Warsaw. [Online]. $\quad$ pp. $185 . \quad$ Available: http://www.mrr.gov.pl/rozwoj_regionalny/Polityka_regionalna/Strate gia_rozwoju_polski_wschodniej_do_2020/Dokumenty/Documents/pr zemysl_w_Polsce_Wsch.pdf .

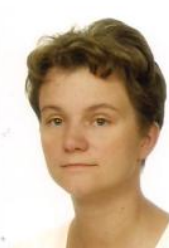

J. Ejdys is employed at the Department of Management, Bialystok University of Technology, Poland. Currently she acts as Vice-Dean of Science Affairs. She obtained a professor degree in 2011 in the field of management science. Her main research interest is the study of the foresight and corporate social responsibility. She has authored over 100 publications in the field of management. She is currently involved in three research projects on foresight issues. She is the scientific coordinator of the project financed by the Ministry of Science and Higher Education National Foresight Programme - results implementation. Prof. Ejdys is a member of the European Association of Economists of Environment and Natural Resources, Production Engineering Association. In 2006, received Brown Cross of Merit of the Polish President. Each year she is the award-winning The Rector of Bialystok Technical University

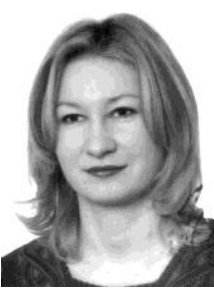

E. Glinska works as an assistant professor at the Faculty of Management, Bialystok University of Technology, Poland. She obtained doctorate degree in 2004 in the field of sociology. Her doctoral thesis was awarded by Polish scientific journal "Samorzad Terytorialny" (Local Government) in 2005. Her main areas of current studies are: place marketing, innovation in city management and foresight. Dr Glinska is the author of over 100 publications. She is involved in research projects on city marketing and foresight issues. 